\title{
HEDGING EMERGING MARKET BONDS AND THE RISE OF THE CREDIT DEFAULT SWAP
}

\author{
Frank S. Skinner* \\ and \\ Julinda Nuri
}

April 16, 2007

JEL Classification: $G 13, G 15, G 24$

Key words: Emerging market bonds, Credit default swap, Brady bonds, Futures contracts, Hedging.

\footnotetext{
* Frank S. Skinner (corresponding author) and Julinda Nuri is a professor and a lecturer of Finance respectively at the School of Management, University of Surrey, Guildford, Surrey, GU2 7XH, the United Kingdom, Tel +44 (0) 148368 6364, Fax +44 (0) 148368 6346, E-Mail

F.Skinner@surrey.ac.uk. We would like to thank George Wang for comments. An earlier draft of this paper was presented to the Financial Management Association's and the Multinational Finance Society's 2006 meetings, and Emerging Markets Finance and Economics Conference, Istanbul, 2006. Any errors are our own.
} 


\section{ABSTRACT \\ HEDGING EMERGING MARKET BONDS AND THE RISE OF THE CREDIT DEFAULT SWAP}

On October 5, 2001, when credit spreads were widening, the Chicago Mercantile Exchange CME de-listed the full menu of emerging market Brady bond futures contracts. This is intriguing because at a time when interest in hedging and speculating in emerging market sovereign credit risk should be at its peak, the CME de-listed precisely the sort of contract designed to hedge and speculate in sovereign credit risk. This paper finds statistical evidence suggesting that the developing over the counter CDS contract acted as a substitute product for the Brady bond futures contract thereby undermining the Brady bond futures contract and contributing to its demise. 


\section{HEDGING EMERGING MARKET BONDS AND THE RISE OF THE CREDIT DEFAULT SWAP}

\section{INTRODUCTION}

Since the mid 1990's investors could hedge and speculate on emerging market debt by trading in Brady bond futures contracts. In total there were six futures contracts written on Brady bonds issued by Argentina, Brazil and Mexico and were traded on the Chicago Mercantile Exchange CME. Yet on October 5, 2001, when emerging market credit spreads were widening, these six CME futures contracts ceased to trade. This is intriguing since one would suppose that these contracts would be most in demand at times of great uncertainty. For instance Figure 1 shows that on the day that these futures contracts were withdrawn, the medium term ( 7 to 10 year) yield spread over the 10 year on the run US Treasury note of the US dollar denominated bonds of Argentina, Brazil, Venezuela and Mexico widened to almost 5,000, 1,000, 500 and 200 basis points respectively.

[Figure 1 about here]

According to Black's (1986) model one reason why a futures contract can fail is the availability of an alternative hedging instrument. Nothaft, Lekkas and Wang (1995) find that the existence of an alternative hedging instrument is associated with the demise of the mortgage backed futures contract. The purpose of this paper is to present evidence that the rise of the maturing credit default swap CDS market may have contributed to the demise of the exchange traded Brady futures contracts by forming a superior hedging alternative to the menu of Brady bond futures contracts.

In fact this paper clearly demonstrates that indeed CDS contracts can perform better as a hedging instrument than the exchange traded Brady bond futures contract. A statistical test conducted in an out of sample framework is applied to a group of actively quoted bonds to determine if apparent improvements in hedging effectiveness are significant. In the first half of the sample CDS contracts yield statistically significant superior hedge performance for only three of the twelve emerging market bonds that are hedged. In contrast in the second half of the sample CDS contracts yield statistically significant superior hedge performance for eight of twelve bonds. 
This suggests that the hedge performance of the CDS contract improved over time cutting into the main raison de être of the Brady bond futures contracts. Eventually the CME realised that hedgers and speculators in emerging market debt would not return to the exchange and so withdrew the Brady bond futures contracts on October $5,2001$.

These results have three implications. First they illustrate that the developing CDS market improved the effectiveness of hedging Sovereign risk to the point where exchange traded futures contracts specifically designed to tackle this problem were made redundant. Secondly, it demonstrates that exchange traded products face competition with innovations in the less transparent over the counter market. Thirdly, these findings point the way for the exchange traded futures market to respond to such competition. Specifically, an exchange traded CDS futures contract can trade based on an average of surveyed values of over the counter CDS contracts. This possibility is not merely hypothetical as already the two, five and ten year interest rate swap and the one-month Libor futures contracts are trading on this basis on the CME.

The rest of this paper is organised as follows. The first section reviews the Brady bond and the CDS market literature and explains the rationale for developing the emerging market Brady bond futures contract. Section II discusses the data and Section III discusses the methodology. Section IV presents and discusses the empirical results while section $\mathrm{V}$ concludes.

\section{THE BRADY BOND AND CREDIT DEFAULT SWAP MARKETS}

Periodically the world's financial system is shaken by large sovereign bank loan defaults obligating bailouts by the World Bank and the International Monetary Fund, often in co-operation with OECD countries. In 1989, the US Treasury secretary Michael Brady sought a market-based solution by designing a tradable financial contract that the defaulted sovereign and their creditors could accept as a substitute for defaulted sovereign bank loans. The idea is to substitute defaulted US dollar bank loans with a new market traded bond denominated in US dollars. Although the sovereign is always fully responsible for repayment of interest and principal in a 
timely manner, sometimes credit risk is reduced because some portion of the bond is defeased by U.S. Treasury zero-coupon bonds.

There are two main types of Brady bonds, par and discount bonds. Par bonds are Brady bonds that replace banks loans at face value but pay below market value interest. Discount bonds replace bank loans at below face value but pay market rates of interest. Therefore both types of Brady bonds involve some economic loss to the original lender but in return the original lender is able to sell the bonds and remove the loans from their balance sheet. ${ }^{1}$

This innovation proved popular and "Brady bonds" became the preferred debt instrument used to bail out many Sovereigns in financial difficulty. Soon these Brady bonds developed many innovations of their own such as floating coupon payment bonds and were often denominated in other major currencies such as pounds sterling, euros and yen. Investors were interested in these bonds as these instruments allowed them to add sovereign risk to their portfolios. In turn however, this led to the demand for a Brady bond hedging instrument as investors sought to control the amount of sovereign risk thereby added to their portfolio.

Ahn, Boudoukh, Richardson and Whitelaw (1998) study the problem of hedging Brady bonds. Using data that ends in December 1996 they find that only about $15 \%$ of the variance of Brady bonds could be hedged using the 10-year T-note futures contract as the hedging instrument. This was the case even through they also used a hedge ratio adjusted for state variables that proxy for the level of US interest rates, the probability of default and the maturity of the Brady bond. Evidently at that time the futures market did not span the outcomes pre-packaged in a Brady bond so hedging was ineffective.

The CME responded to this need by offering a menu of six Brady bond futures contracts, two each for Argentinean, Brazilian and Mexican Brady bonds. Specifically they introduced futures contracts written on a floating rate Argentinean, Argentine FRB, a Brazilian fixed rate, Brazil EI and a Mexican Par Brady bond Mexican PAR in 1996 followed in 1997 by futures contracts written on an Argentinean Par Brady 
bond, Argentine PAR, a fixed rate Brazilian Brady, Brazil C BARRA and a Mexican CETES bond all of which were US dollar denominated.

Some of these futures contracts enjoyed a moderate amount of success. Table 1 reports the open interest of all six Brady bond futures contracts. It is notable that some contracts such as the Argentinean floating rate Brady bond futures contract initially enjoyed a considerable amount of interest while others such as the Argentinean par Brady bond futures contract never traded at all. In other cases such as the Brazil EI Brady and the Mexico Brady bond futures contract we observe long periods of trading inactivity followed by spurts in trading as hedgers and speculators respond to changes in uncertainty and return to the Brady bond futures market. After March 1999 however, no Brady bond futures contract traded. Nevertheless the CME continued to list these contracts, hoping that interest would pick up, and provided daily settlement quotes that is later shown to be reasonable accurate.

[Table 1 about here]

Eventually the CME became discouraged by the lack of trading in Brady bond futures contracts such that on October 5, 2001 all six Brady bond futures contracts were withdrawn from the CME. This is surprising as credit risk, as measured by the credit spread as shown in Figure 1, was rising. It is during times of increasing credit risk one would expect that interest in these futures contracts would pick up as they have in the past as investors seek to hedge and speculate in this volatile environment. It is this surprising lack of interest in Brady bond futures contracts that this paper seeks to explain.

Meanwhile the credit derivative market developed in parallel to the Brady bond market. These innovative instruments allow investors to trade credit risk. Like the interest rate swap market of the early 80's, the credit default swap market enjoyed explosive growth. The British Bankers Association BBA estimates that from January 1996 to December 2001 the notional principal amount of all credit derivatives outstanding grew one hundred fold, from $\$ 20$ billion to nearly $\$ 2$ trillion of which around $45 \%$ are credit default swaps (See BBA, 1996, 2002). Early problems such as a lack of standard products and documentation and regulatory uncertainty were soon 
overcome. The more difficult issue of how to price these instruments was clarified by credit derivative pricing models of Jarrow, Lando and Turnbull (1997), Das and Sundaram (1998) and Duffie and Singleton (1999) amongst others.

The interesting feature of CDS contracts, the most popular credit derivative, is that they can act as a substitute product for those wishing to control the risk of adding Brady bonds to their portfolio. A CDS can be likened to an insurance contract where payoffs are typically conditional upon a formal definition of default on the insured bond. In the parlance of the credit default swap market the insured bond is the reference security. Typical default payments are par less the value of the defaulted reference security. In turn the buyer of credit protection pays a swap premium quoted as a number of basis points times a notional principal amount of the reference security. The swap premium is quoted at annual rates, but swap premium payments are typically paid quarterly. If the reference security should default, the buyer of credit protection would receive the default payment and the flow of swap premium payments would cease.

The above suggests that an investor in Brady bonds can control Sovereign credit risk by purchasing a CDS written on a Brady bond because the Brady bond CDS would pay off only when the Sovereign experiences a credit event and pay nothing otherwise. Moreover as the prospects of Sovereign default changes, so too will the price of the CDS. Alternatively the investor can hedge Sovereign credit risk by shorting exchange traded Brady bond futures contracts.

It is not obvious which alternative will prove to be superior. The major difference between the exchange traded futures contract and the over the counter CDS is cost. The CDS requires quarterly insurance payments that can be extraordinarily expensive if the reference bond is close to default. Meanwhile the futures contract requires more modest mark to market payments to maintain the margin account within the safety margin.

Otherwise there is not much to choose from when comparing Brady bond futures and CDS contracts as potential hedging instruments. Exchange traded futures contracts have the advantages of enhanced liquidity caused by transparency, standardized 
contracts and reduced counterparty credit risk. On the other hand, exchanged traded futures contracts are so standardized that they lack flexibility. In contrast over the counter contracts are more flexible but less liquid, as pricing is less transparent, contracts are less standardized, and there are no contractual safeguards against counterparty default. However these stylized differences have narrowed in recent years as the growth in the CDS market implies greater liquidity and this growth is driven by standardized contracts, reduction in regulatory uncertainty and improvements in pricing transparency via model development and acceptance. Therefore the difference in advantages and disadvantages between the exchange traded Brady futures contracts and the over the counter CDS contracts may have narrowed so that it is simply an empirical issue as to which alternative forms the better hedging instrument.

In summary the issue is whether the CDS contract forms a hedge so effective that it overcomes its disadvantage of extra cost vis á vis the Brady bond futures contract. The prerequisite is that the CDS contract must form a superior hedge and it is this aspect of the issue this paper concentrates on.

\section{DATA}

The first step is to select the bonds that are to be hedged. The collection procedure initially considers all US dollar denominated Argentinean, Brazilian, Mexican and Venezuelan Brady and international bonds that are available on Bloomberg on May 5, 2001. Bonds of the first three countries examine the hedging performance of the full menu of CME futures contracts available prior to May 5, 2001. The Venezuelan bonds examine the cross hedging performance of the CME Brady futures contracts on bonds of geographically related countries. ${ }^{2}$ Including international bonds increase the sample size. These international bonds are obligations of sovereigns that have Brady bonds outstanding and so should have a similar risk profile as the Brady bonds. The sample includes only those bonds where the bid price on Bloomberg changed from one day to the next for more than 95\% of the business days from April 1, 1999 to October 5, 2001. Sarig and Warga (1989) point out that quoted prices that do not change from day to day are liable to be stale and inaccurate. In summary the bond 
data consists of daily closing bid prices of twelve Brady and international bonds, four Argentinean, three Brazilian and Mexican and two Venezuelan bonds, details of which are reported in Table II.

[Table 2 about here]

The next step is to select the futures contracts that will be used as hedging instruments. Initially we select a wide range of potential hedging instruments including the two, five, ten and fifteen-year T-note futures, the one-month LIBOR and the S\&P 500 futures, six Brady bond futures contracts and two, five and ten year CDS for Argentina, Brazil, Mexico and Venezuela. However all the T-note futures, the one month LIBOR and S\&P 500 futures contracts performed poorly in sample as well as out of sample. Therefore for the sake of brevity we concentrate our attention on the competing Brandy Bond futures and CDS contracts in hedging emerging market bonds. ${ }^{3}$

We select the six Brady bond futures contracts that traded on the CME until May 5, 2001, specifically the Argentine FRB, Argentine PAR, Brazil C BARRA, Brazil EI, Mexican PAR and the Mexican CETES bond futures contracts, details of which are contained in Table III. An unresolved issue however, is how accurate are the CME reported settlement prices when the underlying contract did not trade after March 1999.

[Table 3 about here]

To gage the quality of CME quotes, daily changes in the CME quotes $\Delta \mathrm{P}_{\mathrm{Bft}}$ are regressed against daily changes in the price of bonds $\Delta \mathrm{P}_{\mathrm{Bt}}$. In other words the following regression is run.

$\Delta \mathrm{P}_{B t}=\alpha+\beta \Delta \mathrm{P}_{B f t}+\mu_{t}$

As discussed later the $\mathrm{R}^{2}$ of this regression represents how closely the daily change in bond price $\Delta \mathrm{P}_{\mathrm{Bt}}$ and futures price $\Delta \mathrm{P}_{\mathrm{Bft}}$ are related and can be interpreted as a measure 
of hedge effectiveness. Equation (1) is run for three bonds, the floating rate Argentina bond of March 29, 2049, the floating rate Brazil bond of April 5, 2004 and the $11.375 \%$ Mexico bond of September 25, 2016, against the corresponding sovereign Brady bond futures contracts. ${ }^{4}$ These three bonds are selected because they were actively quoted from the date that the corresponding Brady bond futures contracts were first offered until the end of the sample period. These regressions are run using a constant sample size of 220 trading days by rolling the regression period forward one day at a time while simultaneously dropping the first observation each time the sample rolls forward one day. Each regression series begins at the date the Brady bond futures contract commenced trading and continues until August 17, 2001. ${ }^{5}$

A plot of the $\mathrm{R}^{2}$ for each series reveals that there is no "cliff" where the $\mathrm{R}^{2}$ suddenly drops once the Brady bond futures contract no longer trades. Also the $\mathrm{R}^{2}$ of periods when Brady bond futures were trading do not appear any different than the $\mathrm{R}^{2}$ of periods when Brady bond futures were not trading. In summary there appears to be no evidence that the lack of trading in the underlying futures contracts resulted in a gross deterioration in quality of the data. The CME supplied quotes appear to contain useful information concerning the hedging opportunities provided by the menu of Brady bond futures contracts.

It is not surprising that Brady bond futures quotes contain useful information concerning the hedging effectiveness of Brady bond futures contracts even though the futures contract did not actually trade for much of the period under study. Brady bond futures contracts are written on cash assets whose primary demand is for investment purposes so the relationship between the cash asset's price and its' corresponding futures price is guided by strong arbitrage free relationships (see Hull 2005, page 97 for details). Therefore given the underlying cash asset's price (which does actively trade) the theoretically correct futures price can be obtained from this relation without the guidance of trading activity in the futures market. As the standard textbook treatment of this relationship does not cover the case of futures contracts written on cash assets subject to credit risk we present the formal arbitrage free relationship in the Appendix. 
The futures data consists of daily settlement prices. Castelino (1992) warns that futures contracts lifted far from expiration have lower hedge ratios than those lifted closer to maturity. To assure the results are comparable, the nearest maturing futures contract is used as the hedging instrument. However, at the expiry month, the data switches to the next maturing contract.

The final step is to select the CDS contracts that will be used as hedging instruments. The CDS data consists of daily quoted prices for two, five and ten year CDS for Argentina, Brazil, Mexico and Venezuela. ${ }^{6}$ Each CDS price reflects the annual number of basis points, paid in quarterly installments, that investors must make to insure a bond from default for two, five and ten years respectively. These CDS swap quotes are generic in the sense that they represent insurance prices for any US dollar denominated bond of the corresponding sovereign for the contracted period of insurance. Based on a notional principal amount of $\$ 100$, and knowing the basis point price and the maturity and therefore the number of quarterly installments, it is a trivial matter to convert CDS basis point prices into dollar prices. Specifically the basis point price converts into dollar prices based on a $\$ 100$ notional principal amount by present valuing the cash flow stream of each CDS contract using the two, five and ten year constant maturity US Treasury bond yields as reported by the Federal Reserve Bank of New York.

The CDS prices were available from April 1, 1999 until May 22, 2002. Given that the Brady bond futures contracts were withdrawn on October 5, 2001 the dataset contains daily observations for fifteen potential hedging instruments and twelve emerging market bonds from April 1, 1999 until October 5, 2001.

In summary this paper will hedge twelve Brady and international bonds of Argentina, Brazil, Mexico and Venezuela using nine hedging instruments. Specifically the hedging instruments are the two, five and ten year CDS contracts for Argentina, Brazil, Mexico and Venezuela and the six Brady bond futures contracts, namely the Argentine FRB, Argentine PAR, Brazil C BARRA, Brazil EI, Mexican PAR and the Mexican CETES bond futures contracts. 


\section{METHODOLOGY}

The next step is to choose the statistical methodology. This paper estimates hedge ratios according to Ederington (1979) where the measure of hedging effectiveness is the $\mathrm{R}^{2}$ from an OLS regression of the daily Brady bond's price change $\Delta \mathrm{P}_{\mathrm{B}}$ on say, the daily price change on the Brady bond futures contract $\Delta \mathrm{P}_{\mathrm{Bf}}$. In this regression the slope parameter $\beta$ is a measure of the minimum variance hedge ratio. OLS is preferred to an error correction model because Lien (2005a, b) shows that OLS can provide a superior hedge ratio in an out of sample context even when the statistical properties of the data favor the error correction model. Price changes are preferred as Terry (2005) shows that OLS hedge ratios computed from price changes are variance minimizing but the same hedge ratio computed from log returns or percentage returns are not variance minimizing. In summary the hedge ratio $\beta$ is from the OLS regression as previously shown in (1).

However, the $\mathrm{R}^{2}$ from (1) is only an in sample measure of hedge effectiveness because it presumes that the hedger can use the hedge ratio at the beginning of the hedge period when in fact this statistic cannot be known until the end of the period. Specifically (1) is run on the entire sample period until date $t$ to hedge from date t- 1 to $t$ and so uses information that cannot be known at the beginning of the hedge period at date $\mathrm{t}-1$.

An out of sample test provides a more rigorous measure of hedge effectiveness and is formed in the following way. First run an OLS regression on the first 220 data points in the sample to estimate the hedge ratio $\beta$. Then form a hedge portfolio consisting of the target Brady bond to be held long $\mathrm{V}_{\mathrm{B}}$ and a number of hedging instruments to be held short $\mathrm{V}_{\mathrm{Bf}}$ as indicated by the hedge ratio $\beta$. This forms the following hedge portfolio $\mathrm{V}_{\mathrm{h}}$ at the end of the $220^{\text {th }}$ day.

$$
\mathrm{V}_{\mathrm{h}}=\mathrm{V}_{\mathrm{B}}-\beta \mathrm{V}_{\mathrm{Bf}}
$$

Then measure the value of (2) one day later to measure the unexpected gains/losses (hedging errors) $\mathrm{H}$ on the hedge portfolio that evolves by the end of the 221 st day. 
Subscripting the value of the Brady bond and Brady bond futures contract by 220 and 221 to represent the price of the instrument at the end of the $220^{\text {th }}$ and $221^{\text {st }}$ day respectively the hedging error is measured as follows.

$\Delta \mathrm{V}_{\mathrm{h}}=\left(\mathrm{V}_{\mathrm{B}, 220}-\mathrm{V}_{\mathrm{B}, 221}\right)-\beta\left(\mathrm{V}_{\mathrm{Bf}, 220}-\mathrm{V}_{\mathrm{Bf}, 221}\right)=\mathrm{H}$

Repeating this process by rolling the estimation period forward each day, dropping the first data point in the estimation period to maintain a consistent sample size, and forming the hedge portfolio one day later obtains a sequence of hedging errors. In this way the hedge is formed at time $t$ using information that is available at time $t$ to hedge during period $t+1$. However, it was noticed that in the weeks leading up to the withdrawal of the Brady bond futures contracts from the CME the incidence of repeat observations of the same daily settlement price increased clearly indicating that interest in these contracts was waning. To avoid possible reliance on stale and unrepresentative data, the out of sample tests end on August 17, 2001, seven weeks prior to the withdrawal of the Brady bond futures contracts from the CME. This means that the out of sample tests run from February 2, 2000 to August 17, 2001, 402 daily observations in all.

A measure of the out of sample hedge effectiveness is a ratio defined as,

$$
P=1-\left[\frac{\sum H^{2}}{\sum C^{2}}\right]
$$

Here $P$ is the "protection ratio", $\Sigma \mathrm{H}^{2}$ is the sum of squared hedging errors for the sequence of hedge portfolios and $\Sigma \mathrm{C}^{2}$ is the sum of squared gains and losses for the target bond to be hedged. Hence this protection ratio is a relative measure indicating how successful the hedge is in reducing the variation in the target emerging market bond's gains and losses. If the hedging errors were all zero the above ratio would be 1 representing a perfect hedge. More realistically there will be hedging errors but as long as hedging errors are smaller than the target bond's gains and losses, the above ratio will be greater than zero. This represents some degree of hedging, the closer to one, the better. Ratios less than zero would indicate that the hedge failed in that the 
squared hedging errors were greater than the bond's squared gains and losses. In other words, instead of reducing the range of outcomes, the hedge actually increased them. Thinking of $\Sigma \mathrm{H}^{2}$ as the "error sum of squares" and $\Sigma \mathrm{C}^{2}$ as the "total sum of squares", the above ratio is seen as analogous to $\mathrm{R}^{2}$, but unlike $\mathrm{R}^{2}$ a negative protection ratio $P$ can occur.

The objective is to compare the protection ratio estimated by hedging a given bond with say a CDS contract with the analogous protection ratio obtained by hedging the same bond with say a Brady bond futures contract. The instrument that obtains the highest protection ratio is the most effective hedging instrument. However one protection ratio can be larger than another merely due to chance. Therefore it is necessary to use a statistical test so that statistical inferences can be made regarding the significance of differences in protection ratios.

The standard procedure for testing the statistical significance of differences in the size of statistics like the protection ratio $\mathrm{P}$ is to conduct an $F$-test. However this test will not be valid in this case since an $F$-test of the protection ratio $\mathrm{P}$ is critically dependent upon the assumption of independently distributed hedging errors H. Since out of sample tests comparing two hedging alternatives are used to hedge the same bond the hedging errors are not statistically independent so the usual $F$-test is not valid. However Snedecor and Cochran (1989) provide a test that resolves this problem. ${ }^{7}$

Two new variables, S and D are each constructed from two series of hedging errors, each series is formed from hedging the same bond but using a different hedging instrument. $\mathrm{S}$ is formed by the sum of two series of hedging errors and $\mathrm{D}$ is formed by the difference of two series of hedging errors. For instance $\mathrm{S}$ can be formed by taking the hedging errors produced by hedging a given bond with CDS contracts and adding them to the hedging errors produced by hedging the same bond with Brady futures contracts. Similarly subtracting the two series of hedging errors can form D. Snedecor and Cochran (1989) show that if the sample correlation between these two constructed variables $\mathrm{S}$ and $\mathrm{D}$ is significantly negative then the first hedging instrument, the CDS contract in the example, produces a significantly lower hedging error than the second hedging instrument, Brady bond futures in the example. 
Correspondingly, if the correlation is significantly positive, then the Brady bond futures contract forms a more effective hedge than the CDS contract and if the correlation is insignificant then both hedging instruments are equally good in reducing hedging error.

\section{EMPIRICAL RESULTS}

Out of sample hedges are formed 402 times, each day from February 2, 2000 to August 17, 2001, for each of nine hedging instruments to hedge 12 emerging market bonds, a total of 43,416 out of sample tests in all. Table 4 reports the out of sample hedge performance as measured by the protection ratio. The Panel A of Table 4 reports the protection ratio for the entire out of sample period while Panel B reports the protection ratio for the first half and Panel $\mathrm{C}$ reports the protection ratio for the second half of the out of sample hedging period. For each panel the first column reveals the target bond to be hedged and the second column reports the realised price variance for each bond thereby giving some idea of the amount of risk that is to be hedged for each bond. Columns three to eleven report the protection ratio, the measure of out of sample hedging performance, for each of the nine hedging instruments.

[Table 4 about here]

Clearly Panel A shows that CDS contracts dominate the Brady bond futures contracts as hedging instruments for the entire sample period by achieving the highest protection ratios for eleven of the twelve target bonds. The sole exception is the $13.625 \%$ Venezuelan bond where the most effective hedging instrument is the Brazilian BARRA futures contract.

However these findings obscure some interesting information that is more fully revealed through an examination of the sub periods. In Panel B it is evident that during the first half of the sample period the menu of Brady bond futures competed more effectively with CDS contracts, as they were able to form the most effective hedge in nearly half of the twelve target emerging market bonds that we wish to 
hedge. In contrast Panel $\mathrm{C}$ reveals that during the second half of the sample period only two bonds are more effectively hedged using Brady bond futures contracts. Clearly these findings indicate that the hedging performance of the Brady bond futures contracts is deteriorating while the hedging performance of the CDS market is improving in the period leading up to the withdrawal of the Brady bond futures contract from the CME. The question now arises whether these differences in hedge effectiveness were statistically significant.

Table 5 (a) reports the statistical significance of the differences in hedge effectiveness as reported in Table 4, panel A for the entire out of sample period. Similarly Tables 5 (b) and (c) report the corresponding statistical significance of the differences in hedge effectiveness for the first and second half of the out of sample period respectively as reported in panels $\mathrm{B}$ and $\mathrm{C}$ of Table 4.

[Table $5 \mathrm{a}, \mathrm{b}$ and $\mathrm{c}$ about here]

Turning first to the overall results Table 5 (a) reports that the case for the CDS contract is more compelling. Specifically for the $13.625 \%$ Venezuela bond of 2018 , the only instance when a Brady bond futures contract has a protection ratio greater than the menu of CDS contracts, the protection ratio achieved when hedging using the Brazilian BARRA futures contract is not significantly greater than the protection ratio achieved when using a two year CDS contract. On the other hand, in the remaining eleven instances when Table 4 panel A reports a larger protection ratio for a CDS contract, nine of these are significantly greater than the protection ratios achieved by the entire menu of Brady bond futures contracts at least at the 5\% significance level. Clearly the hedge effectiveness of CDS contracts dominates the hedge effectiveness of the Brady bond futures contracts in a statistically significant way for the overall out of sample period.

Looking now at the sub period results, the story of the deteriorating hedge effectiveness for Brady bond futures contracts and improving hedge effectiveness for CDS contracts is bolstered by the statistical tests. Specifically for the first half of the sample period Table 4 panel B reports that a Brady bond futures contract achieves the highest protection ratio in five instances but now Table 5 (b) reports that the 
improvement in the protection ratio over the next best CDS contract is never statistically significant. In the meantime Table 4 also reports that the CDS contract has a superior hedge performance in the remaining seven instances but now Table 5 (b) reports that only three of the seven are statistically significant. Evidently it appears that the CDS contract has the edge on the Brady bond futures contract in the first half of the sample period, but the case for the CDS contract is not compelling.

However the CDS contract dominates the Brady bond futures contract in the second half of the sample. Specifically Table 4 panel $\mathrm{C}$ reports that a Brady bond futures contract achieves the highest protection ratio in only two instances none of which are significantly greater than the next best CDS contract as reported by Table 5 (c). In the meantime Table 4 panel $\mathrm{C}$ also reports that the CDS contract has a superior hedge performance in the remaining ten instances and now Table 5 (b) reports that eight of these ten are statistically significant.

Clearly Tables 4 and 5 are presenting a story. At first the Brady bond futures contracts were able to compete reasonably well with the CDS market in hedging emerging market sovereign bonds but as the CDS market continued to develop the CDS contract performed better as a hedging instrument. Evidently, as credit spreads widened in 2001, hedgers used the CDS market rather than return to the exchange traded futures market thereby discouraging the CME. Eventually the CME gave up hope that traders would return to the Brady bond futures market and de-listed these securities on October 5, 2001.

\section{CONCLUSIONS}

This paper investigates an empirical puzzle. Specifically at the height of the last credit risk cycle when interest in hedging and speculating in sovereign credit risk would be at its peak, the CME withdrew the full menu of Brady bond futures contracts, precisely the sort of contract designed to hedge and speculate in sovereign credit risk. Since the Brady bond futures data are CME supplied quotes rather than trade prices this paper first examines the quality of the Brady bond futures quote data. This examination finds that CME supplied quotes based on arbitrage free arguments 
contain useful information concerning the hedging opportunities provided by the menu of Brady bond futures contracts.

This paper presents evidence that the demise of the Brady bond futures contracts is related to the rise of the emerging CDS market. Specifically the out of sample tests find that while the CDS contract often formed a superior hedging instrument to the menu of Brady bond futures contracts that were available in the first half of the sample period the differences in hedge performance were statistically significant for only three of twelve emerging market bonds in the sample. However in the second half of the sample period leading up to the date that the CME withdrew all Brady bond futures contracts, the CDS contract achieved a superior hedge performance that was significantly greater than all possible Brady bond futures contracts for eight of the twelve bonds in the sample. In summary this paper finds evidence that at first the Brady bond futures contracts were able to compete reasonably well with the CDS market but as the CDS market continued to develop the CDS contract performed better as a hedging instrument.

The results of this paper implies that the developing CDS market improved the effectiveness of hedging Sovereign risk to the point where exchange traded futures contracts specifically designed to tackle this problem were made redundant. Moreover, it suggests that exchange traded products face competition with innovations in the less transparent over the counter market. The results also indicate the way forward for the exchange traded futures market to respond to such competition. Specifically, it is possible that an exchange traded futures contract can be constructed based on an average of surveyed CDS values to provide a cheap method for traders to hedge and speculate in sovereign credit risk. 


\section{APPENDIX}

The following arbitrage free argument closely follows Hull (2005) but has been adapted to include a futures contract written on an asset subject to credit risk. The following hedging argument applies as the asset underlying the futures contract is held primarily for investment purposes. See Hull (2005, page 97) for details.

Consider the following two portfolios.
1. $\mathrm{f}+\mathrm{Kexp}^{-\mathrm{rfT}}$
2. B - Cexp ${ }^{-r f \tau}-\mathrm{P}$

The instruments in portfolio 1 are $\mathrm{f}$, a long position in a futures contract written on a bond $\mathrm{B}$ subject to credit risk committing the long position to buy the bond at date $\mathrm{T}$, and an investment in a zero coupon risk free bond that at maturity $\mathrm{T}$ pays off the amount $\mathrm{K}$ needed to fulfil the commitment to purchase the bond subject to credit risk under the terms of the futures contract. The instruments in portfolio 2 are a long position in the bond subject to credit risk B, borrowings at the risk free rate maturing at date $\tau(0<\tau<\mathrm{T})$ that requires the repayment of $\mathrm{C}$ which is the same amount as the promised coupon payable on the bond B at date $\tau$, and finally the immediate payment of a premium $\mathrm{P}$ on a credit default swap on $\mathrm{C}$ units of bond $\mathrm{B}$. The last instrument is designed to insure the coupon payment on the bond subject to credit risk should the bond default at date $\tau$.

Portfolios 1 and 2 both have the same cash flow payoffs in all states of nature. To demonstrate this, consider the following diagram that outlines all possible scenarios until maturity at date $\mathrm{T}$. 
$\mathrm{t}=0$

$t=\tau$

$\mathrm{t}=\mathrm{T}$

$\downarrow$

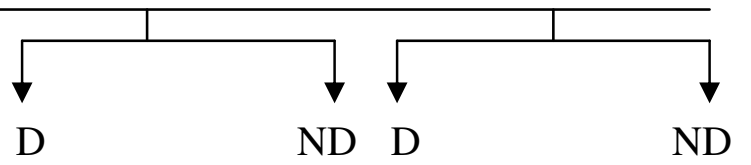

1. $f+\operatorname{Kexp}^{-\mathrm{rfT}}$

0

0

$\mathrm{B}_{\mathrm{d}}$

B

2. B - $\exp ^{- \text {-rf } \tau}-\mathrm{P}$

$-\mathrm{C}+\mathrm{C} \quad-\mathrm{C}+\mathrm{C} \quad \mathrm{B}_{\mathrm{d}}$

B

At intermediate date $\tau$ the bond can default $\mathrm{D}$ or not default ND. Nothing is payable from portfolio 1 at date $\tau$ in any event. The borrowing of $C$ is due at date $\tau$ from portfolio 2 in any event and needs to be netted to zero in order to match the cash flow structure of portfolio 1 . Should the bond default, the credit default swap pays $\mathrm{C}$ units of bond $\mathrm{B}$ and is used to repay the borrowings $\mathrm{C}$ so not net cash flow is received from portfolio 2 should the bond $\mathrm{B}$ default. If the bond does not default at time $\tau$ then the borrowing $\mathrm{C}$ is repaid from the coupon $\mathrm{C}$ received from the bond $\mathrm{B}$. Meanwhile the CDS expires worthless. Therefore at date $\tau$ the net cash flow structure of portfolio 2 matches the cash flow structure 1.

At maturity date $\mathrm{T}$ the bond can default $\mathrm{D}$ or not default ND. The delivery price $\mathrm{K}$ available from the maturing zero coupon bond is used to satisfy the delivery requirements on the maturing futures contract $f$ so portfolio 1 is worth $B_{d}$ if the bond is in default or B if the bond is not in default. Portfolio 2 is worth $B_{d}$ if the bond is in default and $\mathrm{B}$ if the bond is not in default since the only remaining instrument in portfolio 2 is a long position in the bond $\mathrm{B}$. Therefore at date $\mathrm{T}$ the net cash flow structure of portfolio 2 matches the cash flow structure 1.

Since it is known that portfolio 1 is worth the same as portfolio 2 in all possible future states of nature then to prevent arbitrage portfolio 1 and 2 must have the same price today.

$\mathrm{f}+\mathrm{Kexp}^{-\mathrm{rfT}}=\mathrm{B}-\mathrm{Cexp}^{-\mathrm{rf} \tau}-\mathrm{P}$

By definition, the futures price $\mathrm{F}$ is that delivery price $\mathrm{K}$ that resets the value of the futures contract $f$ to zero. Imposing this condition the above is re-written below.

$\operatorname{Fexp}^{-\mathrm{rfT}}=\mathrm{B}-\mathrm{Cexp}^{-\mathrm{rf} \tau}-\mathrm{P}$

Solving the above expression for the futures price $\mathrm{F}$ we obtain the desired result.

$\mathrm{F}=\left(\mathrm{B}-\mathrm{C} \exp ^{-\mathrm{rf} \tau}-\mathrm{P}\right) \exp ^{\mathrm{rfT}}$ 
In other words the futures price $\mathrm{F}$ on a futures contract written on an instrument subject to credit risk is the same as the futures price on a futures contract written on an asset not subject to credit risk $\left(F=\left(B-C \exp ^{-r f \tau}\right) \exp ^{\text {rfT }}\right.$, see Hull 2005, page 97) less the future value of a credit default swap premium $P$ that insures the nominal value of any coupon payment promised prior to maturity of the futures contact. The great point of this appendix is that there exists a strong arbitrage free relation that dictates what the futures price should be given observable values of $\mathrm{B}, \mathrm{C}, \mathrm{rf}$ and $\mathrm{P}$. This implies that the CME is able to report reasonable settlement prices that are useful for hedging purposes even though the underlying futures contract did not often trade. 


\section{REFERENCES}

Ahn, D. Boudoukh J. Richardson M. and Whitelaw R.F., 1998. Hedging the interest rate risk of Bradys: the case of Argentinean fixed and floating-rate bonds. In R. Levich (ed.), Emerging Market Capital Flows, Kluwer Academic Publishers, pp. 307317.

BBA. 1996. Credit Derivatives Report, British Bankers Association.

BBA. 2002. 2001/2002 Credit Derivatives Survey, British Bankers Association.

Black, D.G., 1986. Success and failure of futures contracts: theory and empirical evidence, Monograph series in Finance and Economics 1986-1, Salomon Brothers Center, New York University.

Castelino, M., 1992. Hedge effectiveness: Basis risk and minimum-variance hedging. The Journal of Futures Markets. 12, 187-201.

Das, R.S. and Sundaram, R., 1998. A direct approach to arbitrage-free pricing of credit derivatives. NBER, Working Paper 6635.

Duffie, D. and Singleton K., 1999. Modeling term structures of defaultable bonds. Review of Financial Studies. 12, 687-720.

Ederington, L., 1979. The Hedging Performance of the new futures markets. Journal of Finance. 34, 157-170.

Hull J., 2005. Fundamentals of futures and options markets, fifth ed. Prentice Hall, Upper Saddle River, New Jersey.

Jarrow, R. Lando, D. and Turnbull, S., 1997. A markov model for the term structure of credit spreads. The Review of Financial Studies. 10, 481-523.

Lien, D., 2005a. A Note on the superiority of the OLS hedge ratio. The Journal of Futures Markets. 25, 1121-1126.

Lien, D. 2005b. The use and abuse of the hedging effectiveness measure, International Review of Financial Analysis 14, 277-282.

Nofthaft, F. Vassilis Lekkas, E. and Wang, G.H.K., 1995. The failure of the mortgage-backed futures contract. The Journal of Futures Markets. 15, (5), 585-603.

Sarig, O. and Warga, A., 1989. Bond price data and bond market liquidity. Journal of Financial and Quantitative Analysis. 24, 367-378.

Snedecor, G. and Cochran, W., 1989. Statistical Methods. eighth ed. Ames, IA: Blackwell Publishing.

Terry, E., 2005. Minimum-variance futures hedging under alternative return specifications. The Journal of Futures Markets. 25, 537-552. 
Table 1

This table shows the open interest by month for the following Brady bond futures contracts, Argentina Floating Rate Brady bond futures, AR FRB, Argentina Par Brady bond futures, AR PAR, Brazil BARRA Brady futures, BR Bara, Brazil EI Brady bond futures, BR Brad, Mexico Brady bond futures MX Brad and Mexico CETAS bond futures, MX CET.

\begin{tabular}{rrrrrrr} 
& AR FRB & AR PAR & BR Bara & BR Brad & MX Brad & MX Cetas \\
Jul-96 & 437 & 0 & 0 & 0 & 122 & 0 \\
Aug-96 & 369 & 0 & 0 & 0 & 122 & 0 \\
Sep-96 & 330 & 0 & 0 & 0 & 121 & 0 \\
Oct-96 & 375 & 0 & 0 & 0 & 2 & 0 \\
Nov-96 & 378 & 0 & 0 & 0 & 1 & 0 \\
Dec-96 & 453 & 0 & 0 & 0 & 1 & 0 \\
Jan-97 & 170 & 0 & 0 & 0 & 0 & 0 \\
Feb-97 & 350 & 0 & 0 & 0 & 0 & 0 \\
Mar-97 & 255 & 0 & 0 & 0 & 0 & 0 \\
Apr-97 & 221 & 0 & 0 & 0 & 0 & 0 \\
May-97 & 181 & 0 & 0 & 0 & 0 & 391 \\
Jun-97 & 261 & 0 & 0 & 0 & 0 & 493 \\
Jul-97 & 0 & 0 & 0 & 0 & 0 & 415 \\
Aug-97 & 225 & 0 & 0 & 0 & 10 & 533 \\
Sep-97 & 10 & 0 & 0 & 0 & 70 & 626 \\
Oct-97 & 50 & 0 & 0 & 0 & 50 & 218 \\
Nov-97 & 50 & 0 & 0 & 0 & 46 & 267 \\
Dec-97 & 15 & 0 & 0 & 0 & 20 & 234 \\
Jan-98 & 15 & 0 & 0 & 0 & 0 & 120 \\
Feb-98 & 15 & 0 & 0 & 0 & 0 & 47 \\
Mar-98 & 5 & 0 & 0 & 0 & 0 & 100 \\
Apr-98 & 0 & 0 & 0 & 0 & 0 & 18 \\
May-98 & 0 & 0 & 0 & 0 & 0 & 25 \\
Jun-98 & 0 & 0 & 0 & 0 & 0 & 35 \\
Jul-98 & 0 & 0 & 0 & 0 & 0 & 0 \\
Aug-98 & 0 & 0 & 0 & 0 & 0 & 0 \\
Sep-98 & 0 & 0 & 0 & 0 & 0 & 0 \\
Oct-98 & 0 & 0 & 0 & 0 & 0 & 0 \\
Nov-98 & 0 & 0 & 0 & 1050 & 0 & 0 \\
Dec-98 & 0 & 0 & 0 & 1050 & 0 & 0 \\
Jan-99 & 0 & 0 & 0 & 1050 & 0 & 1 \\
Feb-99 & 0 & 0 & 0 & 1872 & 0 & 1 \\
Mar-99 & 0 & 0 & 0 & 1872 & 0 & 1 \\
\hline & & 0 & 0 & 0 & 0 \\
\hline
\end{tabular}


Table 2

This table reports the salient details of the bond issues that we attempt to hedge using exchange traded futures and the over the counter CDS contracts. Trading frequency is the ratio of the number of business days that the bid price changed to the number of business days in the sample period from April 1, 1999 to October 5, 2001.

\begin{tabular}{|c|c|c|c|c|c|c|c|c|}
\hline Issuer & ISIN & Issue Date & Maturity & Coupon & $\begin{array}{l}\text { Amount in } \\
\text { millions \$ }\end{array}$ & Bond Type & $\begin{array}{l}\text { Collateral / } \\
\text { Seniority }\end{array}$ & $\begin{array}{l}\text { Trading } \\
\text { Frequency } \\
\text { (in \%) }\end{array}$ \\
\hline Argentina & XS0043120236 & $03 / 31 / 93$ & $03 / 29 / 49$ & Libor $+81.25 \mathrm{bp}$ & 8,467 & Brady & US Treasury Zeros & 97.01 \\
\hline Argentina & US040114BE93 & 04/07/99 & 04/07/09 & 11.75 & 1,500 & International & Unsubordinated & 99.00 \\
\hline Argentina & US040114AR16 & $01 / 30 / 97$ & $01 / 30 / 17$ & 11.625 & 4,575 & International & Unsubordinated & 98.01 \\
\hline Brazil & XS0049977191 & $04 / 15 / 94$ & $04 / 14 / 12$ & Libor $+87.5 \mathrm{bp}$ & 8,490 & Brady & US Treasury Zeros & 95.77 \\
\hline Brazil & US105756AH38 & 04/30/99 & 04/05/04 & 11.625 & 3,000 & International & Unsubordinated & 98.75 \\
\hline Mexico & US593048BB61 & $01 / 14 / 97$ & $01 / 15 / 07$ & 9.875 & 1,500 & International & Unsubordinated & 97.23 \\
\hline Mexico & US593048BA88 & 09/24/96 & $09 / 15 / 16$ & 11.375 & 2,395 & International & Unsubordinated & 96.77 \\
\hline Venezuela & XS0029435491 & $12 / 18 / 90$ & $12 / 18 / 07$ & Libor $+87.5 \mathrm{bp}$ & 5,353 & Brady & US Treasury Zeros & 95.28 \\
\hline Venezuela & US922646AT10 & $08 / 06 / 98$ & $08 / 15 / 18$ & 13.625 & 500 & International & Unsubordinated & 96.18 \\
\hline
\end{tabular}


Table $3^{*}$

This table reports the details of the contract specifications of the Chicago Mercantile Exchange Brady bond futures contracts applicable during the sample period from April 1, 1999 to October 5, 2001.

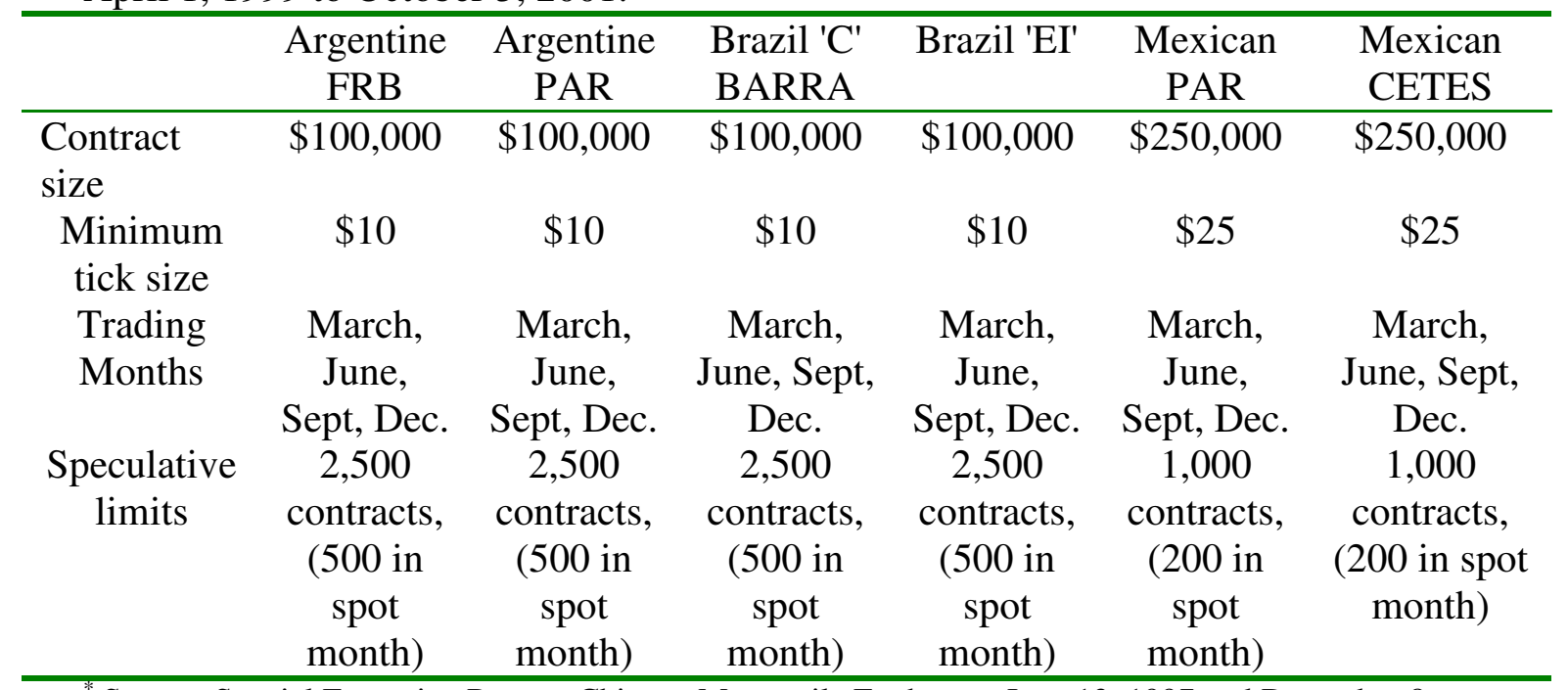

* Source, Special Executive Report, Chicago Mercantile Exchange, June 13, 1997 and December 8, 1997. 
Table 4

This table shows the out of sample hedge effectiveness as measured by the protection ratio. The most effective value is highlighted in bold. The dollar price variance of the bond to be hedged is $\sigma_{\text {Bond. The hedging instruments are the two }}^{2}$ year CDS, CDS 2, five year CDS, CDS 5, ten year CDS, CDS 10, Argentina Floating Rate Brady bond futures, AR FRB, Argentina Par Brady bond futures, AR PAR, Brazil BARRA Brady futures, BR Bara, Brazil EI Brady bond futures, BR Brad, Mexico Brady bond futures MX Brad and Mexico CETAS bond futures, MX CET.

Panel A: Full sample-February 2, 2000 to August 17, 2001

\begin{tabular}{|c|c|c|c|c|c|c|c|c|c|c|}
\hline $\begin{array}{l}\text { Instrument (coupon, } \\
\text { issuer, maturity) }\end{array}$ & $\sigma_{\text {Bond }}^{2}$ & CDS 2 & CDS 5 & $\begin{array}{c}\text { CDS } \\
10\end{array}$ & $\begin{array}{c}\text { AR } \\
\text { FRB }\end{array}$ & $\begin{array}{c}\text { AR } \\
\text { PAR }\end{array}$ & $\begin{array}{c}\text { BR } \\
\text { Bara }\end{array}$ & $\begin{array}{c}\text { BR } \\
\text { Brad }\end{array}$ & $\begin{array}{l}\text { MX } \\
\text { Brad }\end{array}$ & $\begin{array}{l}\text { MX } \\
\text { Cetas }\end{array}$ \\
\hline Float. Argentina 1/49 & 37.024 & 60.52 & 57.63 & 53.35 & 0.33 & 13.51 & 28.46 & 22.83 & 1.65 & -0.18 \\
\hline 11 Argentina 10/06 & 33.267 & 30.88 & 36.44 & 51.03 & 0.31 & 12.31 & 20.62 & 19.51 & 0.77 & -0.43 \\
\hline 11.75 Argentina 7/09 & 65.609 & 47.60 & 50.30 & 48.88 & 9.40 & 12.70 & 27.86 & 23.16 & 1.50 & -0.40 \\
\hline 11.375 Argentina $1 / 17$ & 46.080 & 44.37 & 47.42 & 43.50 & 16.40 & 12.57 & 28.91 & 17.45 & 1.56 & -0.43 \\
\hline Float. Brazil 4/12 & 0.488 & 27.98 & 31.63 & 56.49 & 6.77 & 12.27 & 47.36 & 27.79 & 6.22 & -1.47 \\
\hline 11.625 Brazil 4/04 & 0.176 & 46.72 & 41.25 & 55.77 & 6.28 & 16.81 & 43.06 & 36.55 & 8.69 & -0.61 \\
\hline 14.50 Brazil 10/09 & 1.213 & 42.32 & 42.69 & 63.45 & 11.52 & 17.79 & 50.21 & 34.31 & 8.55 & -5.11 \\
\hline 9.75 Mexico 4/05 & 0.068 & 27.22 & 35.56 & 22.44 & 5.48 & 10.32 & 17.35 & 9.81 & 22.33 & -3.21 \\
\hline 9.875 Mexico 1/07 & 0.163 & 27.01 & 37.55 & 31.61 & 5.60 & 11.12 & 21.01 & 10.14 & 22.27 & -1.94 \\
\hline 11.375 Mexico 9/16 & 1.518 & 22.91 & 31.27 & 33.52 & 6.95 & 15.07 & 30.32 & 15.01 & 23.47 & -0.70 \\
\hline Float. Venezuela 12/07 & 0.165 & 23.46 & -3.57 & -4.28 & 0.57 & 8.58 & 18.76 & 10.49 & 4.46 & -2.25 \\
\hline 13.625 Venezuela 8/18 & 1.491 & 7.55 & -9.65 & -8.81 & -2.06 & 3.30 & 9.26 & 3.77 & -0.83 & -2.70 \\
\hline \multicolumn{11}{|c|}{ Panel B: First Half of Sample-February 2, 2000 to November 9, 2000} \\
\hline Float. Argentina 1/49 & 0.117 & 42.19 & 59.98 & 51.96 & 59.10 & 37.99 & 33.45 & 24.28 & 8.29 & -0.36 \\
\hline 11 Argentin & 0.733 & 32.58 & 40.85 & 33.96 & 29.19 & 27.38 & 10.95 & 8.41 & 5.54 & 0.01 \\
\hline 11.75 Argentina 7/09 & 1.728 & 31.35 & 48.52 & 44.97 & 40.54 & 39.68 & 25.99 & 18.03 & 7.23 & -0.06 \\
\hline 11.375 Argentina $1 / 17$ & 1.040 & 24.27 & 42.91 & 35.10 & 45.30 & 42.78 & 34.34 & 20.99 & 8.00 & -0.09 \\
\hline Float. Brazil 4/12 & 0.338 & 2.00 & -4.67 & 47.42 & 25.60 & 22.16 & 51.08 & 31.53 & 12.37 & -0.39 \\
\hline 11.625 Brazil 4/04 & 0.042 & 2.95 & -15.25 & 45.56 & 21.10 & 21.94 & 43.10 & 37.71 & 20.33 & -1.39 \\
\hline 14.50 Brazil 10/09 & 0.490 & 2.29 & -7.46 & 52.64 & 32.62 & 34.23 & 60.33 & 45.12 & 23.42 & 5.74 \\
\hline 9.75 Mexico 4/05 & 0.130 & 34.75 & 44.95 & 27.09 & 12.64 & 13.25 & 20.34 & 11.16 & 28.07 & -2.99 \\
\hline 9.875 Mexico 1/07 & 0.313 & 34.82 & 43.88 & 35.71 & 12.10 & 14.11 & 21.08 & 9.65 & 26.74 & -1.09 \\
\hline 11.375 Mexico 9/16 & 2.632 & 23.63 & 32.78 & 36.07 & 15.47 & 21.13 & 32.62 & 16.53 & 30.27 & -0.62 \\
\hline Float. Venezuela 12/07 & 0.212 & 14.82 & -27.26 & -25.18 & 11.08 & 11.81 & 18.94 & 12.10 & 4.98 & -0.95 \\
\hline 13.625 Venezuela $8 / 18$ & 2.850 & 3.08 & -17.56 & -15.25 & 0.28 & 2.29 & 6.96 & 2.96 & -1.61 & -0.84 \\
\hline \multicolumn{11}{|c|}{ Panel C: Second Half of Sample-November 10, 2000 to August 17, 2001} \\
\hline Float. Argentina 1/49 & 71.422 & 61.82 & 57.47 & 53.45 & -3.82 & 11.78 & 28.11 & 22.72 & 1.18 & -0.16 \\
\hline 11 Argentina 10/06 & 62.209 & 30.70 & 35.96 & 52.89 & -2.84 & 10.67 & 21.67 & 20.72 & 0.25 & -0.48 \\
\hline 11.75 Argentina 7/09 & 125.14 & 50.03 & 50.57 & 49.46 & 4.74 & 8.67 & 28.14 & 23.92 & 0.65 & -0.45 \\
\hline 11.375 Argentina $1 / 17$ & 88.502 & 48.48 & 48.34 & 45.21 & 10.49 & 6.39 & 27.80 & 16.73 & 0.24 & -0.50 \\
\hline Floating Brazil 4/12 & 0.638 & 50.40 & 62.96 & 64.32 & -9.48 & 3.74 & 44.15 & 24.57 & 0.91 & -2.40 \\
\hline 11.625 Brazil 4/04 & 0.302 & 66.39 & 66.64 & 60.35 & -4.23 & 11.09 & 40.71 & 33.43 & -0.29 & -4.41 \\
\hline 14.50 Brazil 10/09 & 1.906 & 66.40 & 72.85 & 69.95 & -3.08 & 6.13 & 43.04 & 26.38 & -2.37 & -13.91 \\
\hline 9.75 Mexico 4/05 & 0.003 & -0.31 & 1.22 & 5.40 & -20.74 & -0.38 & 6.42 & 4.86 & 1.32 & -4.03 \\
\hline 9.875 Mexico 1/07 & 0.009 & 4.10 & 19.01 & 19.58 & -13.48 & 2.36 & 20.81 & 11.58 & 9.18 & -4.46 \\
\hline 11.375 Mexico 9/16 & 0.320 & 20.92 & 27.06 & 26.44 & -16.66 & -1.75 & 23.93 & 10.80 & 4.64 & -0.90 \\
\hline Float. Venezuela 12/07 & 0.114 & 37.49 & 34.91 & 29.66 & -16.51 & 3.34 & 18.47 & 7.89 & 3.63 & -4.36 \\
\hline 13.625 Venezuela 8/18 & 0.078 & 22.97 & 17.62 & 13.39 & -10.13 & 6.78 & 17.19 & 6.59 & 1.87 & -9.10 \\
\hline
\end{tabular}


Table 5 (a)

This table shows the results of the out of sample hedge effectiveness test as measured by the correlation test for the entire sample period, from February 2 , 2000 to August 17, 2001. The first data column reports the most effective hedging instrument and its protection ratio PR. All other data cells are the correlation between the sum and the difference in hedging errors of the most effective hedging instrument and the alternative hedging instrument. All data is in percent. The hedging instruments are the two year CDS, CDS 2, five year CDS, CDS 5, ten year CDS, CDS 10, Argentina Floating Rate Brady bond futures, AR FRB, Argentina Par Brady bond futures, AR PAR, Brazil BARRA Brady futures, BR Bara, Brazil EI Brady bond futures, BR Brad, Mexico Brady bond futures MX Brad and Mexico CETAS bond futures, MX CET.

\begin{tabular}{|c|c|c|c|c|c|c|c|c|c|c|}
\hline $\begin{array}{l}\text { Instrument (coupon, issuer, } \\
\text { maturity) }\end{array}$ & $\begin{array}{l}\text { Best Hedge } \\
(\mathrm{PR})\end{array}$ & $\begin{array}{l}\text { Best Vs. } \\
\text { CDS2 }\end{array}$ & $\begin{array}{l}\text { Best Vs. } \\
\text { CDS5 }\end{array}$ & $\begin{array}{l}\text { Best Vs. } \\
\text { CDS10 }\end{array}$ & $\begin{array}{l}\text { Best Vs. } \\
\text { AR FRB }\end{array}$ & $\begin{array}{l}\text { Best Vs. } \\
\text { AR PAR }\end{array}$ & Best Vs. BR BARA & $\begin{array}{l}\text { Best Vs. } \\
\text { BR BRAD }\end{array}$ & $\begin{array}{l}\text { Best Vs. } \\
\text { MX BRAD }\end{array}$ & $\begin{array}{l}\text { Best Vs. } \\
\text { MX CET }\end{array}$ \\
\hline Floating Argentina 1/49 & $\begin{array}{l}\text { CDS } 2 \\
(60.52)\end{array}$ & $\mathrm{N} / \mathrm{A}$ & -9.23 & $-12.78^{\star *}$ & $-44.21^{\star \star *}$ & $-39.54^{\star \star \star}$ & $-30.10^{* \star *}$ & $-33.80^{\star \star *}$ & $-45.19^{\star \star \star}$ & $-46.05^{\star \star \star}$ \\
\hline 11 Argentina 10/06 & $\begin{array}{l}\text { CDS 10 } \\
(51.03)\end{array}$ & $-30.80^{* * *}$ & $-29.92^{* \star *}$ & $\mathrm{~N} / \mathrm{A}$ & $-40.34^{\star \star \star}$ & $-35.76^{\star \star \star}$ & $-30.43^{\star \star \star}$ & $-30.50^{\star \star \star}$ & $-43.47^{\star \star \star}$ & $-44.27^{\star \star \star}$ \\
\hline 11.75 Argentina 7/09 & $\begin{array}{l}\text { CDS } 5 \\
(50.30)\end{array}$ & -7.19 & $N / A$ & -3.09 & $-30.22^{\star \star \star}$ & $-29.65^{\star \star \star}$ & $-19.24^{\star \star \star}$ & $-22.43^{\star \star \star}$ & $-35.32^{\star \star \star}$ & $-36.40^{\star \star \star}$ \\
\hline 11.375 Argentina $1 / 17$ & $\begin{array}{l}\text { CDS } 5 \\
(47.42)\end{array}$ & -8.27 & $N / A$ & -6.60 & $-23.69^{\star * *}$ & $-27.70^{\star * *}$ & $-16.08^{\star \star \star}$ & $-24.35^{\star \star \star}$ & $-33.46^{\star \star \star}$ & $-34.78^{\star \star \star}$ \\
\hline Floating Brazil 4/12 & $\begin{array}{l}\text { CDS } 10 \\
(56.49)\end{array}$ & $-34.62^{\star \star \star}$ & $-32.68^{\star * \star}$ & $\mathrm{N} / \mathrm{A}$ & $-41.81^{* \star *}$ & $-39.94^{\star \star \star}$ & $-11.27^{\star *}$ & $-30.13^{* * \star}$ & $-44.64^{\star \star \star}$ & $-49.81^{\star \star \star}$ \\
\hline 11.625 Brazil 4/04 & $\begin{array}{l}\text { CDS } 10 \\
(55.77)\end{array}$ & $-11.63^{\star *}$ & $-19.17^{\star \star \star}$ & $N / A$ & $-37.47^{\star \star \star}$ & $-32.29^{\star \star \star}$ & $-14.43^{* \star \star}$ & $-19.70^{\star * \star}$ & $-36.51^{\star \star \star}$ & $-40.59^{* \star \star}$ \\
\hline 14.50 Brazil 10/09 & $\begin{array}{l}\text { CDS } 10 \\
(63.45)\end{array}$ & $-26.61^{\star \star \star}$ & $-27.69^{\star \star \star}$ & $\mathrm{N} / \mathrm{A}$ & $-42.17^{\star \star \star}$ & $-39.13^{\star \star \star}$ & $-16.12^{* \star \star}$ & $-29.23^{\star \star \star}$ & $-43.56^{\star * \star}$ & $-49.04^{* \star \star}$ \\
\hline 9.75 Mexico 4/05 & $\begin{array}{l}\text { CDS } 5 \\
(35.56)\end{array}$ & $-13.92^{* \star \star}$ & $N / A$ & $-18.26^{\star \star \star}$ & $-25.28^{\star \star \star}$ & $-21.88^{\star * *}$ & $-17.01^{* \star \star}$ & $-25.36^{\star \star \star}$ & $-12.58^{* *}$ & $-34.10^{* \star \star}$ \\
\hline 9.875 Mexico $1 / 07$ & $\begin{array}{l}\text { CDS } 5 \\
(37.55)\end{array}$ & $-17.68^{* * *}$ & $N / A$ & -8.80 & $-28.21^{* * *}$ & $-23.84^{* \star *}$ & $-16.52^{\star * *}$ & $-28.00^{* * *}$ & $-15.02^{* \star *}$ & $-36.19^{* \star \star}$ \\
\hline 11.375 Mexico 9/16 & $\begin{array}{l}\text { CDS 10 } \\
(33.52)\end{array}$ & $-13.33^{* * *}$ & -3.92 & $N / A$ & $-22.45^{\star \star *}$ & $-16.40^{\star * *}$ & -3.41 & $-18.61^{\star \star \star}$ & -9.10 & $-32.73^{* \star \star}$ \\
\hline Float Venezuela 12/07 & $\begin{array}{c}\text { CDS } 2 \\
(23.46) \\
\text { BR BARA }\end{array}$ & $\mathrm{N} / \mathrm{A}$ & $-25.06^{\star * \star}$ & $-25.59^{* * *}$ & $-20.36^{\star * *}$ & $-15.35^{\star \star \star}$ & -4.76 & $-14.62^{\star \star *}$ & $-19.40^{\star \star \star}$ & $-32.89^{* \star \star}$ \\
\hline & $(9.26)$ & -2.05 & $-16.10^{* * *}$ & $-15.66^{* * *}$ & $-15.54^{* * *}$ & -7.85 & $\mathrm{~N} / \mathrm{A}$ & $-10.97^{* *}$ & $-11.83^{* *}$ & $-13.96^{* * \star}$ \\
\hline
\end{tabular}

Significant at the $1 \%$ level, Critical Value (CV) 12.8, ${ }^{* * *}$ Significant at the 5\% level, CV 9.8, both for 400 degrees of freedom 
Table 5 (b)

This table shows the results of the out of sample hedge effectiveness test as measured by the correlation test for the first half of the sample period, from February 2, 2000 to November 9, 2000. The first data column reports the most effective hedging instrument and its protection ratio P. All other data cells are the correlation between the sum and the difference in hedging errors of the most effective hedging instrument and the alternative hedging instrument. All data is in percent. The hedging instruments are the two year CDS, CDS 2, five year CDS, CDS 5, ten year CDS, CDS 10,

Argentina Floating Rate Brady bond futures, AR FRB, Argentina Par Brady bond futures, AR PAR, Brazil BARRA Brady futures, BR Bara, Brazil EI Brady bond futures, BR Brad, Mexico Brady bond futures MX Brad and Mexico CETAS bond futures, MX CET.

\begin{tabular}{|c|c|c|c|c|c|c|c|c|c|c|}
\hline $\begin{array}{l}\text { Instrument (coupon, issuer, } \\
\text { maturity) }\end{array}$ & $\begin{array}{l}\text { Best Hedge } \\
(\mathrm{PR})\end{array}$ & $\begin{array}{l}\text { Best Vs. } \\
\text { CDS2 }\end{array}$ & $\begin{array}{l}\text { Best Vs. } \\
\text { CDS5 }\end{array}$ & $\begin{array}{l}\text { Best Vs. } \\
\text { CDS10 }\end{array}$ & $\begin{array}{l}\text { Best Vs. } \\
\text { AR FRB }\end{array}$ & $\begin{array}{l}\text { Best Vs. } \\
\text { AR PAR }\end{array}$ & $\begin{array}{l}\text { Best Vs. BR } \\
\text { BARA }\end{array}$ & $\begin{array}{l}\text { Best Vs. } \\
\text { BR BRAD }\end{array}$ & $\begin{array}{l}\text { Best Vs. } \\
\text { MX BRAD }\end{array}$ & $\begin{array}{l}\text { Best Vs. } \\
\text { MX CET }\end{array}$ \\
\hline Floating Argentina 1/49 & $\begin{array}{l}\text { CDS } 2 \\
(61.82)\end{array}$ & $\mathrm{N} / \mathrm{A}$ & $-14.45^{\star *}$ & $-15.14^{\star *}$ & $-47.20^{\star * *}$ & $-41.85^{\star \star \star}$ & $-31.85^{\star \star \star}$ & $-35.28^{\star \star \star}$ & $-46.69^{\star \star \star}$ & $-47.23^{\star \star \star}$ \\
\hline 11 Argentina 10/06 & $\begin{array}{l}\text { CDS 10 } \\
(52.89)\end{array}$ & $-33.20^{* * *}$ & $-33.42^{* * *}$ & $\mathrm{~N} / \mathrm{A}$ & $-43.14^{\star \star \star}$ & $-38.40^{* * *}$ & $-31.47^{* \star \star}$ & $-31.35^{\star \star \star}$ & $-45.43^{\star \star \star}$ & $-45.70^{\star * \star}$ \\
\hline 11.75 Argentina 7/09 & $\begin{array}{l}\text { CDS } 2 \\
(50.03)\end{array}$ & $\mathrm{N} / \mathrm{A}$ & -1.42 & -2.47 & $-32.51^{\star \star *}$ & $-31.84^{\star \star \star}$ & $-19.17^{\star \star \star}$ & $-21.96^{\star \star \star}$ & $-35.72^{\star \star *}$ & $-36.18^{* * *}$ \\
\hline 11.375 Argentina $1 / 17$ & $\begin{array}{l}\text { CDS } 2 \\
(48.48)\end{array}$ & $\mathrm{N} / \mathrm{A}$ & -0.83 & -4.55 & $-27.62^{\star * \star}$ & $-31.26^{\star \star \star}$ & $-17.10^{* *}$ & $-24.53^{\star \star \star}$ & $-33.45^{* \star \star}$ & $-33.80^{\star \star \star}$ \\
\hline Floating Brazil 4/12 & $\begin{array}{l}\text { CDS } 10 \\
(64.32)\end{array}$ & $-26.20^{\star \star \star}$ & -5.11 & $\mathrm{~N} / \mathrm{A}$ & $-55.07^{\star \star \star}$ & $-51.20^{\star \star \star}$ & $-24.86^{\star \star \star}$ & $-40.25^{\star \star \star}$ & $-55.86^{\star * \star}$ & $-57.83^{\star \star \star}$ \\
\hline $\begin{array}{l}11.625 \text { Brazil 4/04 } \\
14.50 \text { Brazil } 10 / 09\end{array}$ & $\begin{array}{l}\text { CDS } 5 \\
(66.64) \\
\text { CDS } 5\end{array}$ & -0.72 & $\mathrm{~N} / \mathrm{A}$ & $-29.42^{* \star *}$ & $-53.32^{\star * \star}$ & $-47.25^{\star \star *}$ & $-30.26^{\star \star \star}$ & $-35.35^{\star \star *}$ & $-51.87^{* \star *}$ & $-53.34^{* \star \star}$ \\
\hline 9.75 Mexico 4/05 & $\begin{array}{c}(72.85) \\
\text { BR BARA }\end{array}$ & $-19.11^{\star \star \star}$ & $N / A$ & -12.96 & $-59.05^{\star * \star}$ & $-55.90^{* * *}$ & $-36.36^{\star \star \star}$ & $-46.98^{\star \star \star}$ & $-58.91^{* \star *}$ & $-62.31^{\star \star *}$ \\
\hline 9.875 Mexico 1/07 & $\begin{array}{c}(6.42) \\
\text { BR BARA }\end{array}$ & -3.28 & -2.72 & 0.66 & $-22.71^{* \star *}$ & -4.37 & $N / A$ & -1.39 & -4.33 & -8.44 \\
\hline 11.375 Mexico 9/16 & $\begin{array}{l}(20.81) \\
\text { CDS } 10 \\
(27.06)\end{array}$ & -12.38 & -0.48 & -0.05 & $\begin{array}{l}-29.23^{\star * *} \\
-27.94^{\star * *}\end{array}$ & $\begin{array}{l}-14.80^{* *} \\
-19.88^{\star * *}\end{array}$ & $\mathrm{~N} / \mathrm{A}$ & $\begin{array}{l}-14.32 \\
-13.56\end{array}$ & $\begin{array}{l}-10.92 \\
-19.34^{* * *}\end{array}$ & $\begin{array}{l}-19.91^{\text {** }} \\
-25.88^{\text {**}}\end{array}$ \\
\hline Float Venezuela 12/07 & $\begin{array}{l}\text { CDS } 10 \\
(34.91)\end{array}$ & -7.89 & $-17.81^{\star *}$ & $\mathrm{~N} / \mathrm{A}$ & $-38.05^{* \star *}$ & $-28.27^{* \star *}$ & $-17.88^{\star \star}$ & $-27.44^{\star \star \star}$ & $-34.22^{* \star \star}$ & $-39.22^{\star \star \star}$ \\
\hline 13.625 Vene & $\begin{array}{l}\text { CDS } 2 \\
(22.97)\end{array}$ & $\mathrm{N} / \mathrm{A}$ & $-17.37^{* *}$ & $-23.34^{\star \star \star}$ & $-24.52^{\star \star *}$ & $-16.27^{\star *}$ & -6.18 & $-15.69^{* *}$ & $-24.54^{\star \star \star}$ & $-32.37^{\star \star \star}$ \\
\hline
\end{tabular}

"Significant at the $1 \%$ level, Critical Value (CV) 18.1," Significant at the 5\% level, CV 13.8, both for 200 degrees of freedom 
Table $5(\mathrm{c})$

This table shows the results of the out of sample hedge effectiveness test as measured by the correlation test for the first half of the sample period, from November 10, 2000 to August 17, 2000. The first data column reports the most effective hedging instrument and its protection ratio P. All other data cells are the correlation between the sum and the difference in hedging errors of the most effective hedging instrument and the alternative hedging instrument. All data is in percent. The hedging instruments are the two year CDS, CDS 2, five year CDS, CDS 5, ten year CDS, CDS 10, Argentina Floating Rate Brady bond futures, AR FRB, Argentina Par Brady bond futures, AR PAR, Brazil BARRA Brady futures, BR Barra, Brazil EI Brady bond futures, BR Brad, Mexico Brady bond futures MX Brad and Mexico CETAS bond futures, MX CET.

\begin{tabular}{|c|c|c|c|c|c|c|c|c|c|c|}
\hline $\begin{array}{l}\text { Instrument (coupon, issuer, } \\
\text { maturity) }\end{array}$ & $\begin{array}{l}\text { Best Hedge } \\
(\mathrm{PR})\end{array}$ & $\begin{array}{l}\text { Best Vs. } \\
\text { CDS2 }\end{array}$ & $\begin{array}{l}\text { Best Vs. } \\
\text { CDS5 }\end{array}$ & $\begin{array}{l}\text { Best Vs. } \\
\text { CDS10 }\end{array}$ & $\begin{array}{l}\text { Best Vs. } \\
\text { AR FRB }\end{array}$ & $\begin{array}{l}\text { Best Vs. } \\
\text { AR PAR }\end{array}$ & $\begin{array}{l}\text { Best Vs. BR } \\
\text { BARA }\end{array}$ & $\begin{array}{l}\text { Best Vs. } \\
\text { BR BRAD }\end{array}$ & $\begin{array}{l}\text { Best Vs. } \\
\text { MX BRAD }\end{array}$ & $\begin{array}{l}\text { Best Vs. } \\
\text { MX CET }\end{array}$ \\
\hline Floating Argentina 1/49 & CDS 2 & & & & & & & & & \\
\hline 11 Argentina 10/06 & $\begin{array}{l}(61.82) \\
\text { CDS } 10\end{array}$ & $\mathrm{~N} / \mathrm{A}$ & $-14.45^{\star \star}$ & $-15.14^{\star *}$ & $-47.20^{\star \star \star}$ & $-41.85^{\star \star \star}$ & $-31.85^{\star \star \star}$ & $-35.28^{\star \star \star}$ & $-46.69^{\star \star \star}$ & $-47.23^{* \star \star}$ \\
\hline & $(52.89)$ & $-33.20^{* * \star}$ & $-33.42^{* * *}$ & $\mathrm{~N} / \mathrm{A}$ & $-43.14^{* \star *}$ & $-38.40^{* * *}$ & $-31.47^{\star \star \star}$ & $-31.35^{\star \star \star}$ & $-45.43^{\star \star \star}$ & $-45.70^{\star \star \star}$ \\
\hline 11.75 Argentina 7/09 & $\begin{array}{l}\text { CDS } 2 \\
(50.03)\end{array}$ & $\mathrm{N} / \mathrm{A}$ & -1.42 & -2.47 & $-32.51^{\star \star \star}$ & $-31.84^{\star \star *}$ & $-19.17^{\star \star \star}$ & $-21.96^{\star \star \star}$ & $-35.72^{\star \star \star}$ & $-36.18^{\star \star *}$ \\
\hline 11.375 Argentina $1 / 17$ & $\begin{array}{l}\text { CDS } 2 \\
(48.48)\end{array}$ & $\mathrm{N} / \mathrm{A}$ & -0.83 & -4.55 & $-27.62^{\star * *}$ & $-31.26^{\star \star *}$ & $-17.10^{\star *}$ & $-24.53^{\star \star \star}$ & $-33.45^{\star \star \star}$ & $-33.80^{\star \star *}$ \\
\hline Floating Brazil 4/12 & $\begin{array}{l}\text { CDS } 10 \\
(64.32)\end{array}$ & $-26.20^{* * *}$ & -5.11 & $\mathrm{~N} / \mathrm{A}$ & $-55.07^{\star \star \star}$ & $-51.20^{\star \star \star}$ & $-24.86^{\star \star \star}$ & $-40.25^{\star \star \star}$ & $-55.86^{\star \star \star}$ & $-57.83^{* \star \star}$ \\
\hline 11.625 Brazil 4/04 & $\begin{array}{l}\text { CDS } 5 \\
(66.64)\end{array}$ & -0.72 & $\mathrm{~N} / \mathrm{A}$ & $-29.42^{* * *}$ & $-53.32^{* \star *}$ & $-47.25^{* * *}$ & $-30.26^{\star \star \star}$ & $-35.35^{\star \star \star}$ & $-51.87^{\star \star \star}$ & $-53.34^{\star \star \star}$ \\
\hline $\begin{array}{l}\text { 14.50 Brazil 10/09 } \\
\text { 9.75 Mexico 4/05 }\end{array}$ & $\begin{array}{c}\text { CDS } 5 \\
(72.85) \\
\text { BR BARA }\end{array}$ & $-19.11^{* * *}$ & $\mathrm{~N} / \mathrm{A}$ & -12.96 & $-59.05^{\star * \star}$ & $-55.90^{* \star *}$ & $-36.36^{\star \star \star}$ & $-46.98^{\star \star \star}$ & $-58.91^{* \star *}$ & $-62.31^{* * *}$ \\
\hline 9.875 Mexico 1/07 & $\begin{array}{c}(6.42) \\
\text { BR BARA }\end{array}$ & -3.28 & -2.72 & 0.66 & $-22.71^{\star * \star}$ & -4.37 & $N / A$ & -1.39 & -4.33 & -8.44 \\
\hline 11.375 Mexico 9/16 & $\begin{array}{l}(20.81) \\
\text { CDS } 10\end{array}$ & -12.38 & -0.48 & -0.05 & $-29.23^{* \star *}$ & $-14.80^{* *}$ & $\mathrm{~N} / \mathrm{A}$ & -14.32 & -10.92 & $-19.91^{\star \star \star}$ \\
\hline Float Venezuela 12/07 & $\begin{array}{l}(27.06) \\
C D S 10\end{array}$ & -8.39 & -1.24 & $N / A$ & $-27.94^{\star * \star}$ & $-19.88^{\star \star \star}$ & -3.40 & -13.56 & $-19.34^{\star \star *}$ & $-25.88^{\star \star *}$ \\
\hline Float venezuela $12 / 0 /$ & (34.91) & -7.89 & $-17.81^{* *}$ & $\mathrm{~N} / \mathrm{A}$ & $-38.05^{\star \star \star}$ & $-28.27^{\star * \star}$ & $-17.88^{\star *}$ & $-27.44^{\star \star \star}$ & $-34.22^{\star \star \star}$ & $-39.22^{\star \star \star}$ \\
\hline 13.625 Venezuela $8 / 18$ & $\begin{array}{l}\text { CDS } 2 \\
(22.97) \\
\end{array}$ & $\mathrm{N} / \mathrm{A}$ & $-17.37^{* *}$ & $-23.34^{* \star *}$ & $-24.52^{\star * \star}$ & $-16.27^{\star \star}$ & -6.18 & $-15.69^{* *}$ & $-24.54^{* \star *}$ & $-32.37^{\star \star \star}$ \\
\hline
\end{tabular}

\footnotetext{
Significant at the $1 \%$ level, Critical Value (CV) 18.1, ${ }^{* *}$ Significant at the 5\% level, CV 13.8, both for 200 degrees of freedom
} 
${ }^{1}$ For further details see Http://www.en.wikipedia.org/wiki/Brady_bonds.

${ }^{2} \mathrm{We}$ did not include bonds from other Latin American emerging market countries as they were infrequently traded.

${ }^{3}$ The hedging performance of the T-Note futures, the one-month LIBOR and the S\&P 500 futures contracts are available from the corresponding author upon request.

${ }^{4}$ We did not regress Mexican bond price changes against changes in the price of the Mexico Brady bond futures contract because this futures contract enjoyed four distinct periods of trading/no trading periods. Therefore it is difficult to compare regression performance in trading as opposed to nontrading periods, thereby defeating the purpose of the exercise.

${ }^{5}$ The graphs from this exercise are not included in the paper for the sake of brevity. They are available from the corresponding author upon request. Also, why we chose August 17, 2001 to end this exercise is explained later.

${ }^{6}$ A leading investment bank that wishes to remain anonymous provides the CDS data.

${ }^{7}$ See Snedecor and Cochran (1989), page 192 for details. 